\title{
Checks and Balances on Executive Compensation
}

\author{
Mai Iskandar-Datta \\ Finance Department, Wayne State University, Detroit, USA \\ Email: mdatta@wayne.edu
}

Received November 11, 2013; revised December 13, 2013; accepted January 7, 2014

Copyright (c) 2014 Mai Iskandar-Datta. This is an open access article distributed under the Creative Commons Attribution License, which permits unrestricted use, distribution, and reproduction in any medium, provided the original work is properly cited. In accordance of the Creative Commons Attribution License all Copyrights (C) 2014 are reserved for SCIRP and the owner of the intellectual property Mai Iskandar-Datta. All Copyright (c) 2014 are guarded by law and by SCIRP as a guardian.

Chief executive officers' compensation has always been in the media spotlight, and particularly so since the financial crisis of 2008. The consensus thinking considers executive pay arrangements as a contributor to the financial crisis in which excessive risk taking was allowed unchecked. No one denies that other factors have also been at work. However, the structure of executive compensation in the run-up to the financial crisis provided large equity incentives. And incentives do matter. In this case, they encouraged excessive risk taking by executives and managers without imposing downside penalties from such behavior. Pay structures and corporate governance that has the potential to limit agency problems are sorely needed to ensure a well-functioning economy given the huge capital injections by taxpayers to keep financial institutions alive.

A recent addition to the corporate governance structure is the clawback provision which has the potential to rein in managerial abuses arising from lop-sided pay incentives. Clawback policy can act as a deterrent to selfserving managerial behavior because it mandates ex post settling up. By discouraging distortion in the firm's financial information, the clawback provision can enhance transparency in financial reporting. However, this measure is not without its detractors, especially since DoddFrank Act (Section 954) will soon mandate all publicly traded firms to adopt clawback policies requiring the recoupment of previous compensation in cases of financial restatement.

While most corporate governance experts agree that the clawback measure is appropriate in fraud situations, some consider a blanket policy for any financial restatement problematic. Those who oppose the clawback policy argue that diligent executives may become ensnared in a clawback through no fault of their own or that wayward executives will find ways to avoid the clawback whether through cozy relationship with the board of directors or through avoiding restatement of earnings. Such arguments against recovery measures ignore the fact that allowing executives to keep unearned pay is essentially payment for failure.

There are some encouraging signs that corporations are trying to discourage self-serving behavior. Recently, companies have voluntarily adopted more aggressive clawback provisions than those in the Dodd-Frank Act. Some investment banks have expanded their clawback trigger to cover behavior that leads to large losses or reputational harm to the firm. For example, some clawback policies stipulate cancelling long-term incentives of executives in cases of failure to meet ethical and risk standards even when such actions result in a positive impact on the firm. In addition, firms are beginning to define misconduct more broadly (such as failing to supervise others).

Another development in the clawback measure is requiring recoupment of pay even when the firm does not restate earnings. To deter unnecessary risk taking, drug companies are utilizing policies that require managers to give up pay if their decisions adversely impact the firm (e.g. illegal marketing of drugs) even in the absence of financial restatement. Further, some Swiss banks are implementing a "malus" clause, which is essentially a negative bonus. This clause is intended to remove incentives for short-term profits driven by large risky bets. There are also various initiatives in some European countries to curb the use of golden parachutes while new legislation in Spain intends to discourage big payoffs to outgoing executives. Moreover, Swiss voters approved a referendum on curtailing executive pay as Sweden toughened rules governing bonuses by requiring a large part of bonuses to be withheld for three years.

It is important to point out that recovering executive incentive compensation after scandals or losses is not a cure-all because oftentimes losses far exceed monies recovered. Solutions have to be rooted in better internal corporate governance mechanisms and in executive com- 
pensation structure. These are challenging issues that face the modern corporation. It would seem reasonable to say that executive pay structures that tie bonuses to longterm performance would avoid much of the shorttermism prevalent in pre-crisis era. More research is needed in this area. Specifically, examination of types of internal controls and design of procedures to control excessive risk taking is paramount. We also need to learn more about which compensation schemes and governance structures minimize managerial incentives to manipulate earnings while providing enough incentives to maximize firm value. 